Marzanna K. Witek-Hajduk

Piotr Zaborek

Jolanta Mazur

Andrzej Sznajder

Bartosz Targański

Szkoła Gtówna Handlowa w Warszawie

\title{
Cechy domen internetowych polskich marek eksportowych a specyfika branży
}

\author{
CHARACTERISTICS OF INTERNET DOMAINS \\ OF POLISH EXPORT BRANDS AND SPECIFICS OF \\ A SECTOR
}

\begin{abstract}
Celem artykułu jest odpowiedź na pytanie badawcze: Czy cechy stron internetowych polskich marek adresowanych do krajowych i zagranicznych konsumentów wykazują istotne różnice ze względu na specyfikę branży?

W tym celu zrealizowano badania ilościowe polegające na obserwacji i rejestrowaniu cech witryn internetowych marek eksporterów i uzupełniono o dane wtórne na temat ruchu internetowego oraz wyników finansowych gestorów marek. Zbiorowość badawczą stanowiły 402 najsilniejsze polskie marki dóbr konsumpcyjnych, sprzedawane na rynkach zagranicznych.

Stwierdzono, że relatywnie najwyższy poziom badanych cech witryn WWW wykazują marki odzieży i innych produktów związanych z modą oraz marki pozostałych dóbr trwałego użytku, a najniższy - marki żywności i kosmetyków.
\end{abstract}

Słowa kluczowe: cechy domen internetowych, strony WWW, umiędzynarodowienie, polskie marki

\section{Wprowadzenie}

Dynamiczny wzrost liczby użytkowników Internetu na świecie (w 2015 roku około 3,2 mld osób miało dostęp do Internetu ${ }^{1}$, zaś do 2020 roku liczba ta ma wzrosnąć do $8 \mathrm{mld}^{2}$ ) i możliwości jakie przedsiębiorstwom stwarza upowszechnienie komunikacji on-line w ich relacjach $\mathrm{z}$ interesariuszami, uzasadniają znaczenie badań nad zastosowaniem Internetu $\mathrm{w}$ praktyce przedsiębiorstw. Już u schyłku XX wieku rozwój technologii internetowych zaliczono do kluczowych megatrendów determinujących strategie przedsiębiorstw $^{3}$. Z początkiem XXI wieku ten megatrend jeszcze zyskał na znaczeniu ${ }^{4}$.

${ }_{1}$ Www.broadbandcommission.org/Documents/reports/bb-annualreport2015.pdf, s. 19, [22.11.16].

${ }_{2}$ www.thinkwithgoogle.com/intl/en-gb/article/new-opportunities-in-the-connected-world/, [25.11.16].

3 J.S. Krulis-Randa: Megatrends und Logistik-Management, [w]: J.S. Krulis-Randa, S.W. Hägeli (red.): Megatrends als Herausforderung für das Logistik-Management, Bern/Stuttgart 1992, s.11-24;

K. Przybyłowski, S. Hartley, R. Kerin, W. Rudelius: Marketing, Oficyna Ekonomiczna Kraków 1998, s. 90.

${ }^{4}$ D.O. Stephens: Megatrends in international records management. Information Management, 3(4)/2001, s. 66;

V. Reding: Digital Europe: the Internet mega-trends that will shape tomorrow's Europe, Speech at the 
W tej sytuacji rośnie liczba publikacji dotyczących wpływu Internetu na funkcjonowanie organizacji i całych społeczeństw. Skuteczność instrumentów internetowych $\mathrm{w}$ opracowywaniu $\mathrm{i}$ wdrażaniu strategii przedsiębiorstw, w tym w szczególności strategii marketingowych zwróciła uwagę wielu autorów. Ponieważ Internet nie napotyka barier $\mathrm{w}$ postaci granic państw, $\mathrm{z}$ istoty rzeczy narzędzia internetowe stały się dogodnymi sposobami komunikacji z podmiotami z dostępem do Sieci na całym świecie. Dlatego tematyka internacjonalizacji przedsiębiorstw dzięki Internetowi także stała się przedmiotem naukowych dociekań ${ }^{5}$. Petersen $\mathrm{i}$ in. ${ }^{6}$ zwrócili uwagę na elastyczność reagowania na okazje ujawniające się na różnych rynkach i oszczędność kosztów funkcjonowania na nich, jaką daje Internet. Wśród opracowań analizujących relację pomiędzy zastosowaniem Internetu a umiędzynarodowieniem przedsiębiorstwa nie spotkaliśmy tekstu weryfikującego te zależność w przekroju branżowym. Z tych względów nasze badanie empiryczne stron internetowych o charakterze eksploracyjnym postanowiliśmy podporządkować odpowiedzi na pytanie: Czy cechy domen internetowych polskich marek adresowanych do krajowych i zagranicznych konsumentów wykazują istotne różnice ze względu na specyfikę branży?

Odpowiedzi na to pytanie badawcze służyć miała analiza danych na temat cech witryn internetowych 402 przedsiębiorstw-gestorów najsilniejszych polskich marek ${ }^{7}$ dóbr konsumpcyjnych, które sprzedawane były na rynkach zagranicznych. Zestawienie najsilniejszych polskich marek opracowano na podstawie Rankingu polskich marek 2015 dziennika Rzeczypospolita, uzupełnionego o polskie marki wskazane przez zaproszonych ekspertów.

Dalsze części artykułu prezentują problem badawczy na tle literatury, opisują metodę badania, przedstawiają wyniki analizy danych, wnioski i podsumowanie.

\section{Zastosowanie narzędzi internetowych w dzialaniach marketingowych przedsiębiorstw na rynku krajowym i rynkach zagranicznych}

Autorzy podejmujący tematykę zastosowania Internetu w działaniach marketingowych przedsiębiorstw proponują zarówno ujęcia koncepcyjne, jak i oparte na danych empirycznych. I tak, Shneor i Flaten ${ }^{8}$ dokonują klasyfikacji przedsiębiorstw z uwagi rolę narzędzi internetowych. Pierwsza grupa to przedsiębiorstwa, dla których Internet jest jedynym kanałem marketingowym (Internet-based firms - pure clicks), a

European Internet Foundation Special Event A view of the Digital World in 2025, 2008; P. Đikanović: Implementing information technologies in modern business for better market positioning of companies, Megatrend revija 8 (1)/2011, s.373-385; M. Wawrzyński: Urbanizacja, komunikacja lotnicza, cyfryzacja człowieka - kluczowe megatrendy zmian XXI; [w]: Przyszłość. Świat-Europa-Polska. 2/2012, s.95-116.

${ }^{5}$ S. Saeed: Exporting and the Internet: a conceptual perspective, International Marketing Review, 15 (5) /1998, s. 413-426, P.S. Davis, P.D Harveston: Internationalization and organizational growth: The impact of Internet usage and technology involvement among entrepreneur-led family businesses, Family Business Review 13 (2) /2000, s.107-120, S. Ulrich: Internetbasierte Internationalisierung, Entscheidungsfindung, Umsetzung und Erfolgsmessung, Gabler Verlag, Wiesbaden 2011.

${ }^{6}$ B. Petersen, L.S. Welch, P.W. Liesch: The Internet and Foreign Market Expansion by Firms, MIR: Management International Review, 42 (2)/2002, s.207-221.

${ }^{7}$,Polskie marki” rozumiane są w badaniu jako marki wykreowane przez przedsiębiorstwa wywodzące się z Polski, nawet jeśli zostały te marki przejęte przez firmy z kapitałem zagranicznym (np. E. Wedel).

${ }^{8}$ R.Shneor, B.-T. Flaten: The Internet-Enabled Internationalization Process: A Focus on Stages and Sequences, Journal of e-Business, Vol VIII, Nr 1-2/2008, s.45-52. 
drugą stanowią firmy łączące aktywności on-line i off-line (Internet-enabled firms click\&mortars). Te dwa rodzaje aktywności autorzy traktują jako dwie ścieżki internacjonalizacji przedsiębiorstw. Empirycznej ocenie wyboru ścieżek umiędzynarodowienia brytyjskich średnich firm przez Internet poświęcili swój artykuł Sinkovics i in. ${ }^{9}$. Wyniki analizy wykazały, że o ile zastosowanie narzędzi internetowych generalnie sprzyja eksportowi, to całkowite zastąpienie aktywności off-line aktywnością w Internecie naraża niektóre przedsiębiorstwa na tzw. pułapkę wirtualności. Sugerują zatem, aby instrumenty internetowe stosowane były jako wsparcie operacji mających postać fizyczna.

Badania empiryczne prowadzone zarówno na danych ilościowych, jak i jakościowych dotyczą w szczególności zastosowania Internetu w marketingu międzynarodowym ${ }^{10}$. W tej grupie publikacji znajduja się teksty badające aplikację instrumentów internetowych w celu wspierania eksportu ${ }^{11}$. Relatywnie wiele artykułów dotyczy tematyki relacji między stosowaniem Internetu i umiędzynarodowieniem małych i średnich przedsiębiorstw ${ }^{12}$. Większość $\mathrm{z}$ nich koncentruje się na analizie wybranych rynków narodowych. Wynikiem badan Nguyen $^{13}$ rynku Wietnamu było zidentyfikowanie czynników wspierających zastosowanie Internetu w procesach umiędzynarodowienia. Należą do nich postrzegana przez menedżerów przydatność narzędzi internetowych i łatwość ich używania, a także rynkowa orientacja przedsiębiorstwa. Także Moini i Tesar ${ }^{14}$ upatrują przyczyn gotowości stosowania Internetu $\mathrm{w}$ internacjonalizacji przede wszystkim $\mathrm{w}$ czynnikach wewnętrznych firm. Zauważają, że traktowanie stron internetowych jako skutecznego instrumentu marketingowego zależy od postaw i doświadczenia menedżerów. Wiele publikacji wskazuje na efekt przyspieszenia internacjonalizacji dzięki Internetowi ${ }^{15}$, a przede

\footnotetext{
${ }^{9}$ N. Sinkovics, R.R. Sinkovics, R. J. "Bryan" Jean: The internet as an alternative path to internationalization? International Marketing Review, 30 (2)/2013, s.130-155.

${ }^{10}$ K.A. Saban, S.E. Rau: The Functionality of Websites as Export Marketing Channels for Small and Medium Enterprises, Electronic Markets, 15 (2)/2005, s. 128-135; K. Alrawi: The internet and international marketing. Competitiveness Review, An International Business Journal 17(4)/2007, s.222 - 233.

${ }^{11}$ O. J. Sørensen, S. Buatsi: Internet and exporting: the case of Ghana. Journal of Business \& Industrial Marketing, 17(6)/2002, s. 481-500; P. Kaczmarek-Kurczak: Wykorzystanie stron internetowych przez polskich eksporterów z wybranych branż wysokich, średnich i niskich technologii, MBA, 5/2010, s.61-74.

${ }^{12}$ H. Moini, G. Tesar: The internet and internationalization of smaller manufacturing enterprises, Journal of Global Marketing, 18 (3-4)/2005, s.79-94; Y.-L. Jaw, Ch.-L. Chen: The influence of the internet in the internationalization of SME's in Taiwan, Human Systems Management, 25 (3)/2006, s.167-183; T.D. Nguyen: Factors affecting the utilization of the internet by internationalizing firms in transition markets: Evidence from Vietnam, Marketing Intelligence and Planning, 25 (4) /2007, s.360-376; L.T. Eriksson, J. Hultman, L. Naldi: Small business e-commerce development in Sweden - an empirical survey. Journal of Small Business and Enterprise Development, 15(3)/2008, s.555-570; K. Chulikavit: E-commerce and the international distribution of SMEs. IADIS International Conference e-Commerce 2010; K-M.K. Tseng, R.E. Johnsen: Internationalisation and the internet in UK manufacturing SMEs. Journal of Small Business and Enterprise Development, 18(3)/2011, s.571-593.

${ }^{13}$ T.D. Nguyen: Factors affecting the utilization of the internet by internationalizing firms in transition markets: Evidence from Vietnam, Marketing Intelligence and Planning, 25 (4) /2007, s.360-376

${ }^{14} \mathrm{H}$. Moini, G.Tesar: The internet...,op. cit., s.79-94.

${ }^{15}$ J. Yu, A. de Koning, B.M. Oviatt: Institutional and Economic Influences on Internet Adoption and Accelerated Firm Internationalization, [w]: D.A. Shepherd, J.A. Katz: International Entrepreneurship, Advances in Entrepreneurship, Firm Emergence and Growth, 8, Emerald Group Publishing Limited 2005, s. $85-110$.
} 
wszystkim wdrożeniu nowych form ekspansji zagranicznej ${ }^{16}$, w tym rozwojowi handlu elektronicznego ${ }^{17}$.

Zastosowaniu Internetu $\mathrm{w}$ działaniach marketingowych przedsiębiorstw tak adresowanych do krajowych odbiorców, jak i odbiorców zagranicznych towarzyszy dywersyfikacja narzędzi internetowych. Wciąż jednak witryny WWW przedsiębiorstw i ich marek pełniące zarówno funkcję komunikacyjną, jak i dystrybycyjną należą do ich podstawowego kanonu. W publikacjach dotyczących stron internetowych umiędzynarodowionych przedsiębiorstw rozważany jest też dylemat standaryzacji vs. lokalizacji logo marki, kolorystyki i układu strony, informacji tekstowych czy elementów wizualnych ${ }^{18}$. Wydaje się, że zorientowanie strony na konkretną grupę/grupy adresatów jest podstawowym warunkiem jej skuteczności. W literaturze można spotkać artykuły prezentujące inne ważne ich cechy. Simeon ${ }^{19}$ uważa, że zgodnie z modelem AIPD cztery czynniki decydują o strategicznym potencjale stron internetowych i powinny służyc ich ocenianiu. Sa nimi przyciagnie (attracting), informowanie (informing), pozycjonowanie (positioning) i dostarczanie (delivering). $\mathrm{Z}$ kolei według tzW. formuły $6 \mathrm{C}^{20}$, witryny WWW powinny chrakterysować nastepujące cechy: sposób przyciagania internautów (Capture), zawartość (Content), tworzenie społeczności wokół przedsiębiorstwa/marki (Community), istnienie sklepu internetowego (Commerce), dostosowanie do wymogów nabywców (Customer Orientation) oraz wiarygodność (Credibility). Jako szczególnie ważne wymienia się cztery cechy witryn, to jest ich treść, tworzenie społeczności, dostosowanie do zagranicznych klientów oraz istnienie sklepu internetowego.

Rozwój Internetu i jego upowszechnienie tylko umożliwiły uaktywnienie kontaktów firm $\mathrm{z}$ interesariuszami, ale również wzmocniły pozycję klientów (konsumentów) zwiekszając ich dostępność do informacji, także pochodzących od innych niż przedsiębiorstwa uzytkowników Internetu. Klienci stali się aktywnymi uczestnikami relacji rynkowych na różnych poziomach. W tej sytuacji stosowanie narzędzi internetowych jako platform dialogu i interakcji z klientami zyskiwało na znaczeniu. Wagę interaktywności stron internetowych zauważono już w schyłu XX wieku. Ha i Lincoln $^{21}$ rozumieli ją jako: skłanianie do zabawy (playfulness), danie możliwości wyboru (choice), wywoływanie uczucia przywiązania (connectedness), dostosowanie do gromadzenia danych i prowadzenia dialogu (reciprcal communication). Dostrzeżenie znaczenia interaktywności w publikacjach w kolejnych latach wiązało się z pojawieniem się koncepcji modelu otwartych innowacji, czy intensyfikacją dyskusji na

\footnotetext{
${ }^{16}$ N. Sinkovics, R.R. Sinkovics, R. J. “Bryan” Jean: The internet..., op. cit., s. 130-155.

${ }^{17}$ np. L.T. Eriksson, J. Hultman, L. Naldi: Small business e-commerce development in Sweden - an empirical survey. Journal of Small Business and Enterprise Development, 15(3)/2008, s.555-570; M.Ghobakhloo, D. Arias-Aranda, J. Benitez-Amado: Adoption of e-commerce applications in SMEs, Industrial Management \& Data Systems, 111(8)/2011, s.1238-1269.

${ }^{18}$ S. Okazaki: Searching the web for global brands: how American brands standardise their web sites in Europe, European Journal of Marketing, 39(1/2)/2005, s.87-109; F. Gibb, I. Matthaiakis: A framework for assessing web site localization, The Electronic Library, 25 (6)/2007, s.664-678.

${ }^{19}$ R. Simeon: Evaluating domestic and international Web-site strategies. Internet Research, 9(4)/1999, s.297-308.

${ }^{20}$ D. Chaffey, R. Mayer, K. Johnston, F. Ellis-Chadwick: Internet Marketing, Pearson Education, Edinburgh Gate 2000, s. 326.

${ }^{21}$ L. Ha, J. Lincoln: Interactivity Reexamined: A Baseline Analysis of Early Business Web Sites. Journal of Broadcasting \& Electronic Media, 42 (4)/1998, s.457-474,
} 
temat wartości doświadczanej przez konsumentów (value-in use). Do propagatorów tego podejścia należą m.in. Prahalad i Ramaswamy ${ }^{22}$, którzy zaproponowali model działań przedsiębiorstwa zorientowanego na doświadczenia klientów ${ }^{23}$ oraz Vargo i Lusch ${ }^{24}$.

Znaczna część atrykułów empirycznych na temat relacji pomiędzy stosowaniem narzędzi internetowych i umiędzynarodowieniam przedsiębiorstw skoncentrowana była na badaniu firm jednej branży lub oferujących ten sam produkt, np. wina ${ }^{25}$ lub wybranej grupy produktów, np. artykułów mody ${ }^{26}$. Niewiele zaś jest badań porównujacych aktywność internetową przedsiębiorstw $\mathrm{z}$ różnych branż. Do nich należy tekst klasyfikujący eksporterów na reprezentujących branże niskich, średnich i wysokich technologii. Kaczmarek-Kurczak ${ }^{27}$ zauważył, że większość polskich eksporterów z wszystkich branż produkcyjnych stosuje defensywną strategię w zakresie eksploatacji Internetu i koncentruje się przede wszystkim na dostarczaniu ogólnych informacji, a niewielu wykorzystuje w aktywności międzynarodowej jego interaktywne możliwości. Stwierdził jednak, że przedsiębiorstwa branż wysokich technologii stosują relatywnie szerszy niż przedstawiciele innych grup firm zestaw rozwiązań internetowych w aktywności miedzynarodowej, w tym zagraniczne domeny WWW czy zróżnicowanie wersji językowych serwisu oraz częściej stosują narzędzia umożliwiające interakcję z użytkownikami serwisu. $Z$ badań Okazaki ${ }^{28}$ wynika zaś, że zakres standaryzacji stron internetowych w skali międzynarodowej jest znacząco większy w przypadku marek dóbr konsumpcyjnych trwałego użytku niż dóbr konsumpcyjnych nie zaliczanych do tej kategorii.

\section{Próba i metoda badawcza}

Aby odpowiedzieć na postawione pytanie badawcze, przeanalizowano strony internetowe 402 przedsiębiorstw-gestorów najsilniejszych polskich marek ${ }^{29}$ dóbr konsumpcyjnych, które sprzedawane były na rynkach zagranicznych. Do próby zakwalifikowano marki ujęte $w$ Rankingu polskich marek 2015 dziennika Rzeczpospolita $^{30}$, z którego wyodrębniono marki dóbr konsumpcyjnych sprzedawane na rynkach zagranicznych. Podstawowy zbiór uzupełniono o polskie marki różnych kategorii dóbr konsumpcyjnych wskazane przez panel ekspertów. Badanie przeprowadzono z zastosowaniem opracowanego przez autorów kwestionariusza ankiety obejmującego pytania dotyczące różnych funkcjonalności stron internetowych badanych

${ }^{22}$ C. K. Prahalad, V. Ramaswamy: Co-creating unique value with customers, Strategy and Leadership, 32 (3)/2004, s. 4-9.

${ }^{23}$ J. Mazur, P. Zaborek,: Validating DART Model, International Journal of Management and Economics 44 (1) $/ 2014$, s. $106-125$.

${ }^{24}$ S.L. Vargo, R.F. Lusch: Evolving to a New Dominant Logic in Marketing, Journal of Marketing Vol. 68/2004, s.1-17.

${ }^{25}$ A.J Mills, L. Pitt, S. Sattari: Reading between the vines: analyzing the readability of consumer brand wine web sites, International Journal of Wine Business Research, 24 (3)/2012, s.169-182.

${ }^{26}$ H. Kim, Y.J. Choi, Y. Lee: Web atmospheric qualities in luxury fashion brand web sites, Journal of Fashion Marketing and Management, 19 (4)/2015, s.384-401.

${ }^{27}$ P. Kaczmarek-Kurczak: Wykorzystanie stron...,op.cit., s.61-74.

${ }^{28}$ S. Okazaki: Searching the..., op.cit., s. 87-109.

29 ,Polskie marki” rozumiane są w badaniu jako marki wykreowane przez przedsiębiorstwa wywodzące się z Polski, nawet jeśli zostały te marki przejęte przez firmy z kapitałem zagranicznym (np. E.Wedel).

${ }^{30}$ Rzeczpospolita: Ranking Rzeczpospolitej Polskich Marek 2015, 1 grudnia 2015. 
marek, w tym: liczba i rodzaje wersji językowych, istnienie lub brak różnic w treści i formie (layout) zidentyfikowanych wersji językowych, zakres możliwej interakcji użytkownika ze stroną internetowa, informacje o funkcjonowaniu marki w różnych mediach społecznościowych, istnienie sklepu internetowego w różnych wersjach językowych i możliwość personalizacji zamówień i informacje o warunkach dostawy zamówionych towarów w kraju i za granica. Dane te pozyskano w wyniku obserwacji zawartości oraz funkcjonalności stron internetowych marek. $Z$ kolei dane metryczkowe, pochodza $\mathrm{z}$ bazy danych EMIS. Dotyczą one: całkowitych przychodów, liczby pracowników, liczby zagranicznych rynków sprzedaży, udziału kapitału zagranicznego w kapitale firm. Ponadto wykorzystano dane opisujące ruch internetowy na domenach badanych marek, dostępne w serwisie SimilarWeb (https://www.similarweb.com). Strony WWW zostały opisane ze względu na: całkowita liczbę wizyt w sierpniu 2016, średni czas wizyty, współczynnik odrzuceń (tzw. „bounce rate”), odsetek wizyt z zagranicy. Gromadzenie danych zostało zrealizowane w sierpniu 2016 roku.

Badane marki reprezentowały wszystkie funkcjonujące w Polsce branże dóbr konsumpcyjnych. Sklasyfikowano je w cztery kategorie, spodziewając się różnic wynikających ze specyfiki zaliczonych do nich branż: 1) żywność i napoje, 2) kosmetyki, leki, środki czystości i inne dobra szybko zbywalne, 3) produkty związane z modą i osobistym wizerunkiem, takie jak odzież, obuwie, akcesoria i biżuteria, 4) pozostałe dobra trwałego użytku, obejmujące m.in. produkty techniczne, często o relatywnie wysokiej cenie, takie jak elektronika użytkowa, gry komputerowe, elementy wyposażenia wnętrz, meble, rowery i jachty (patrz tabela 1).

Tabela 1. Rozkład próby ze względu na profil działalności

\begin{tabular}{||l|l|l|}
\hline Kategorie w ujęciu branżowym & Częstość & Udział w \% \\
\hline żywność, napoje & 125 & 31,1 \\
\hline kosmetyki, leki, środki czystości itp. & 62 & 15,4 \\
\hline odziė̇, obuwie, akcesoria, biżuteria & 68 & 16,9 \\
\hline pozostałe dobra trwałego użytku & 147 & 36,6 \\
\hline Ogółem & 402 & 100,0 \\
\hline
\end{tabular}

Źródło: Opracowanie własne.

Badana zbiorowość była zróżnicowana ze względu na wielkość przedsiębiorstw mierzoną liczbą pracowników, wyniki ekonomiczne oraz zaangażowanie międzynarodowe mierzone liczbą zagranicznych rynków sprzedaży. Przeważały wśród nich duże przedsiębiorstwa $\mathrm{z}$ obrotami powyżej 100 milionów złotych $(54,8 \%)$ i zatrudniające 250 lub więcej osób $(53,7 \%)$. Większość badanych podmiotów funkcjonowała na 1-10 zagranicznych rynkach (57,5\%), a najliczniejszą grupę stanowiły firmy sprzedające produkty na 2-3 rynkach (30,7\%). Aż 59,3\% badanych miało wyłącznie polski kapitał, zaś $27,9 \%$ przedsiębiorstw było w całości własnością zagranicznego kapitału.

\section{Cechy domen internetowych i dane ekonomiczne firm w przekroju branż}

Kolejny etap analizy objął porównanie czterech wyszczególnionych kategorii firm wyłonionych przy użyciu kryterium branż ze względu na średnie poziomy zmiennych opisujących takie cechy stron internetowych, jak: kompleksowość rozwiązań, wybrane 
elementy jakości oraz stopień internacjonalizacji. Ponadto porównano podstawowe wskaźniki ekonomiczne przedsiębiorstw.

Wyniki porównania wraz $\mathrm{z}$ rezultatami testów ANOVA podano w tabeli 2 (analiza danych pierwotnych zgromadzonych w trakcie badania) i tabeli 3, (analiza danych wtórnych pozyskanych z istniejących baz danych).

Tabela 2. Porównanie kategorii branżowych badanych przedsiębiorstw ze względu na średnie arytmetyczne zmiennych zagregowanych opisujących cechy stron internetowych

\begin{tabular}{|c|c|c|c|c|c|}
\hline \begin{tabular}{|l|} 
Atrybuty \\
WWW \\
\end{tabular} & Branże & $\mathrm{N}$ & Średnia & $\begin{array}{l}\text { Odchylenie } \\
\text { standardowe }\end{array}$ & ANOVA \\
\hline \multirow{5}{*}{$\begin{array}{l}\text { Liczba } \\
\text { językowych }\end{array}$} & żywność, napoje & 125 & 1,216 & 1,059 & \multirow{5}{*}{$\begin{array}{l}F \quad(3,399) \\
9,238 \\
p<0,001\end{array}$} \\
\hline & kosmetyki, leki, środki czystości itp. & 63 & 1,857 & 1,625 & \\
\hline & odzież, obuwie, akcesoria, biżuteria & 68 & 1,132 & 1,303 & \\
\hline & pozostałe dobra trwałego użytku & 147 & 1,966 & 1,661 & \\
\hline & Ogółem & 403 & 1,576 & 1,477 & \\
\hline \multirow{5}{*}{$\begin{array}{l}\text { Zakres różnic } \\
\text { wyglądzie i treści } \\
\text { stron internetowych }\end{array}$} & żywność, napoje & 125 & 488 &, 867 & \multirow{5}{*}{$\begin{array}{l}F \quad(3,399) \\
2,276 \\
p=0,079\end{array}$} \\
\hline & kosmetyki, leki, środki czystości itp. & 63 &, 429 & 875 & \\
\hline & odzież, obuwie, akcesoria, biżuteria & 68 &, 176 & 455 & \\
\hline & pozostałe dobra trwałego użytku & 147 &, 463 &, 946 & \\
\hline & Ogółem & 403 &, 417 & 849 & \\
\hline \multirow{5}{*}{ Interaktywność } & żywność, napoje & 125 & 264 &, 731 & \multirow{5}{*}{$\begin{array}{l}F \quad(3,399) \\
2,690 \\
p=0,046\end{array}$} \\
\hline & kosmetyki, leki, środki czystości itp. & 63 & 238 & 640 & \\
\hline & odzież, obuwie, akcesoria, biżuteria & 68 &, 485 &, 801 & \\
\hline & pozostałe dobra trwałego użytku & 147 &, 503 & 1,043 & \\
\hline & Ogółem & 403 &, 385 &, 863 & \\
\hline \multirow{5}{*}{$\begin{array}{l}\text { Liczba profil } \\
\text { społecznościowych }\end{array}$} & żywność, napoje & 125 & 1,176 & 1,032 & \multirow{5}{*}{$\begin{array}{l}F \quad(3,399) \\
6,554 \\
p<0,001\end{array}$} \\
\hline & kosmetyki, leki, środki czystości itp. & 63 & 1,254 & 1,107 & \\
\hline & odzież, obuwie, akcesoria, biżuteria & 68 & 1,868 & 1,132 & \\
\hline & pozostałe dobra trwałego użytku & 147 & 1,340 & 1,057 & \\
\hline & Ogółem & 403 & 1,365 & 1,092 & \\
\hline \multirow{5}{*}{$\begin{array}{l}\text { Liczba języków } \\
\text { sklepu internetowego }\end{array}$} & żywność, napoje & 125 &, 008 &, 089 & \multirow{5}{*}{$\begin{array}{l}\mathrm{F} \quad(3,399) \\
8,411 \\
p<0,001\end{array}$} \\
\hline & kosmetyki, leki, środki czystości itp. & 63 &, 175 &, 814 & \\
\hline & odzież, obuwie, akcesoria, biżuteria & 68 & 485 &, 922 & \\
\hline & pozostałe dobra trwałego użytku & 147 & 231 &, 663 & \\
\hline & Ogółem & 403 & 196 & 657 & \\
\hline \multirow{5}{*}{$\begin{array}{l}\text { Liczba } \\
\text { kontaktu } \\
\text { obcym }\end{array}$} & żywność, napoje & 125 & 1,712 & 1,015 & \multirow{5}{*}{$\begin{array}{l}F \quad(3,399) \\
5,609 \\
p=0,001\end{array}$} \\
\hline & ikosmetyki, leki, środki czystości itp. & 63 & 1,810 & 1,014 & \\
\hline & odzież, obuwie, akcesoria, biżuteria & 68 & 1,191 & 1,149 & \\
\hline & pozostałe dobra trwałego użytku & 147 & 1,741 & 973 & \\
\hline & Ogółem & 403 & 1,650 & 1,041 & \\
\hline \multirow{5}{*}{ Liczba form płatności } & żywność, napoje & 125 &, 000 &, 000 & \multirow{5}{*}{$\begin{array}{l}F \quad(3,399) \\
14,703 \\
p<0,001\end{array}$} \\
\hline & kosmetyki, leki, środki czystości itp. & 63 &, 286 & 792 & \\
\hline & odzież, obuwie, akcesoria, biżuteria & 68 & 765 & 1,306 & \\
\hline & pozostałe dobra trwałego użytku & 147 & 259 & 741 & \\
\hline & Ogółem & 403 &, 268 &, 803 & \\
\hline
\end{tabular}

Istotne wyniki testów statystycznych zostały pogrubione.

Źródło: Opracowanie własne. 
Tabela 3. Porównanie kategorii branżowych badanych przedsiębiorstw ze względu na średnie arytmetyczne zmiennych opisujących cechy ruchu internetowego na stronach WWW oraz wybrane wskaźniki ekonomiczne

\begin{tabular}{|c|c|c|c|c|c|}
\hline Zmienne & Branże & $\mathrm{N}$ & Średnia & $\begin{array}{l}\text { Odchylenie } \\
\text { standardowe }\end{array}$ & ANOVA \\
\hline \multicolumn{2}{|c|}{ Całkowita liczbażywność, napoje } & 124 & 15,7 & 34,7 & \multirow{5}{*}{$\begin{array}{l}\mathrm{F} \quad(3,397) \\
3,741 \\
\mathbf{P}=\mathbf{0 , 0 1 1}\end{array}$} \\
\hline wizyt w sierpnil & iu kosmetyki, leki, środki czystości itp. & 63 & 40,0 & 79,4 & \\
\hline \multirow[t]{3}{*}{2016 w tysiącach } & odzież, obuwie, akcesoria, biżuteria & 68 & 105,7 & 198,9 & \\
\hline & pozostałe dobra trwałego użytku & 146 & 166,0 & 626,9 & \\
\hline & Ogółem & 401 & 89,5 & 393,3 & \\
\hline \multirow[t]{5}{*}{ Średni czas wizyty } & żywność, napoje & 122 & $02: 04$ & $01: 45$ & \multirow{5}{*}{$\mid \begin{array}{l}F \quad(3,392) \\
12,529 \\
p<0,001\end{array}$} \\
\hline & kosmetyki, leki, środki czystości itp. & 63 & $02: 14$ & $01: 10$ & \\
\hline & odzież, obuwie, akcesoria, biżuteria & 67 & $03: 34$ & $01: 53$ & \\
\hline & pozostałe dobra trwałego użytku & 144 & $03: 25$ & $02: 51$ & \\
\hline & Ogółem & 396 & $02: 50$ & $02: 16$ & \\
\hline \multirow{5}{*}{$\begin{array}{l}\text { Średnia liczba } \\
\text { wyświetlanych } \\
\text { podczas wizyty }\end{array}$} & onżywność, napoje & 124 & 3,92 & 2,57 & \multirow{5}{*}{$\begin{array}{l}F \quad(3,397) \\
7,478 \\
p<0,001\end{array}$} \\
\hline & kosmetyki, leki, środki czystości itp. & 63 & 3,75 & 1,63 & \\
\hline & odzież, obuwie, akcesoria, biżuteria & 68 & 9,61 & 20,19 & \\
\hline & pozostałe dobra trwałego użytku & 146 & 4,95 & 2,84 & \\
\hline & Ogółem & 401 & 5,23 & 8,82 & \\
\hline \multirow{5}{*}{$\begin{array}{l}\text { Współczynnik } \\
\text { odrzuceń }\end{array}$} & żywność, napoje & 121 & 35,58 & 14,80 & \multirow{5}{*}{$\begin{array}{l}F \quad(3,386) \\
6,772 \\
p<0,001\end{array}$} \\
\hline & kosmetyki, leki, środki czystości itp. & 62 & 37,37 & 12,89 & \\
\hline & odzież, obuwie, akcesoria, biżuteria & 63 & 26,70 & 12,67 & \\
\hline & pozostałe dobra trwałego użytku & 144 & 34,75 & 16,30 & \\
\hline & Ogółem & 390 & 34,12 & 15,11 & \\
\hline \multirow{5}{*}{$\begin{array}{ll}\text { Procent } & \text { wizyt } \\
\text { zagranicy } & \end{array}$} & zżywność, napoje & 124 & 12,07 & 12,32 & \multirow{5}{*}{$\begin{array}{l}F \quad(3,396) \\
4,768 \\
p=0,003\end{array}$} \\
\hline & kosmetyki, leki, środki czystości itp. & 63 & 11,68 & 10,36 & \\
\hline & odzież, obuwie, akcesoria, biżuteria & 68 & 9,01 & 12,81 & \\
\hline & pozostałe dobra trwałego użytku & 145 & 16,00 & 15,75 & \\
\hline & Ogółem & 400 & 12,92 & 13,68 & \\
\hline \multirow[t]{5}{*}{ Liczba pracowników } & $v$ żywność, napoje & 122 & 829 & 1308 & \multirow{5}{*}{$\begin{array}{l}F \quad(3,360) \\
1,926 \\
p=0,125\end{array}$} \\
\hline & kosmetyki, leki, środki czystości itp. & 61 & 466 & 872 & \\
\hline & odzież, obuwie, akcesoria, biżuteria & 52 & 624 & 1478 & \\
\hline & pozostałe dobra trwałego użytku & 129 & 560 & 767 & \\
\hline & Ogółem & 364 & 643 & 1109 & \\
\hline \multirow{5}{*}{$\begin{array}{l}\text { Przychody } \\
\text { roku w } \\
\text { złotych }\end{array}$} & 5 żywność, napoje & 122 & 641,3 & 897,9 & \multirow{5}{*}{$\begin{array}{l}F \quad(3,358) \\
1,366 \\
p=253\end{array}$} \\
\hline & hosmetyki, leki, środki czystości itp. & 61 & 1686,0 & 11288,3 & \\
\hline & odzież, obuwie, akcesoria, biżuteria & 50 & 267,6 & 793,7 & \\
\hline & pozostałe dobra trwałego użytku & 129 & 289,6 & 593,4 & \\
\hline & Ogółem & 362 & 640,4 & 4680,5 & \\
\hline \multirow{5}{*}{$\begin{array}{l}\text { Liczba rynkóv } \\
\text { zagranicznych }\end{array}$} & wżywność, napoje & 105 & 12,6 & 13,0 & \multirow{5}{*}{$\begin{array}{l}F \quad(3,284) \\
6,722 \\
p<0,001\end{array}$} \\
\hline & kosmetyki, leki, środki czystości itp. & 53 & 13,7 & 14,9 & \\
\hline & odzież, obuwie, akcesoria, biżuteria & 38 & 4,9 & 6,7 & \\
\hline & pozostałe dobra trwałego użytku & 92 & 16,2 & 13,8 & \\
\hline & Ogółem & 288 & 12,9 & 13,4 & \\
\hline
\end{tabular}

Istotne wyniki testów statystycznych zostały pogrubione.

Źródło: Opracowanie własne.

Analiza wariancji wskazuje, że spośród 15 rozpatrywanych zmiennych istotne różnice pomiędzy wyróżnionymi kategoriami branż występują w przypadku $13 \mathrm{z}$ nich.

Dokonane porównania wskazują, że najwyższy poziom zaangażowania w prowadzenie stron internetowych dotyczy marek przedsiębiorstw zajmujących się sprzedażą odzieży i innych produktów związanych $\mathrm{z}$ modą oraz producentów pozostałych dóbr trwałego użytku. Wskazują na to najwyższe średnie arytmetyczne dla 
obu kategorii branż ze względu na interaktywność, która jest szczególnie pomocna przy sprzedaży artykułów bezpośrednio wpływających na wizerunek konsumenta, lub wyrobów złożonych technicznie - w obu wypadkach interaktywne rozwiązania na stronach internetowych pozwalają lepiej wyjaśnić cechy oferty/marek i ułatwić wybór, a także komunikować się z konsumentami. Ponadto producenci odzieży wykorzystują największą liczbę mediów społecznościowych, co można wyjaśnić dążeniem do wyróżnienia marek oraz kreowania społeczności użytkowników-lojalnych konsumentów. Najwyższą jakość witryn marek $\mathrm{z}$ tej branży potwierdzają takie wskaźniki, jak: najdłuższy średni czas wizyty, największa liczba stron wyświetlanych podczas przeciętnej wizyty oraz najniższy współczynnik odrzuceń. Producenci pozostałych dóbr trwałego użytku mają tylko nieznacznie niższe (nieistotne statystycznie) wyniki ze względu na liczbę odsłanianych stron i czas trwania przeciętnej wizyty. Najgorsze pod tym względem wyniki mają wytwórcy żywności i kosmetyków, z najniższą interaktywnością, krótkimi czasami wizyt, niską liczbą obejrzanych stron i względnie wysokimi współczynnikami odrzuceń. Co ciekawe, sprzedawcy odzieży i produktów związanych $\mathrm{z}$ modą wykazują najniższy spośród badanych branż stopień umiędzynarodowienia stron internetowych, wynikający $\mathrm{z}$ małej liczby wersji językowych, niewielkich możliwości kontaktu w języku obcym, najniższy odsetek odwiedzających z zagranicy. Mimo częstego oferowania zakupów przez Internet ich sklep internetowy jest zazwyczaj dostępny tylko w polskiej wersji językowej. Relatywnie słaba internacjonalizacja marek produktów związanych z modą sugerowana przez strony internetowe jest potwierdzona przez zdecydowanie najmniejszą średnią liczbę zagranicznych rynków sprzedaży.

Najwyższym stopniem umiędzynarodowienia spośród badanych kategorii firm mierzonym liczbą rynków zagranicznych charakteryzują się wytwórcy pozostałych dóbr trwałego użytku, na co spójnie wskazują dane ekonomiczne i internetowe. W ramach tej branży funkcjonuje wielu producentów tradycyjnych polskich „hitów” eksportowych, takich jak meble, stolarka okienna, jachty czy gry komputerowe. Choć wytwórcy produktów spożywczych wykazują wiele przejawów aktywnej działalności eksportowej, prowadzą strony internetowe, które wydają się nie być pomocne w pozyskiwaniu klientów krajowych, a tym bardziej zagranicznych.

\section{Wnioski i implikacje dla praktyki gospodarczej}

Generalny wniosek jaki wypływa $\mathrm{z}$ przeprowadzonych badań pokazuje niewielkie zaangażowanie polskich eksporterów w doskonalenie stron internetowych ich marek na rzecz dostosowania ich do zagranicznego użytkownika. Potwierdza on obserwację poczynioną przez innego badacza aktywności polskich eksporterów w Internecie ${ }^{31}$.

Wyniki przeprowadzonych badań empirycznych pokazały, że spośród 15 rozpatrywanych $\mathrm{w}$ badaniu cech domen internetowych polskich marek istotne różnice pomiędzy kategoriami branżowymi występują w przypadku $13 \mathrm{z}$ nich. Relatywnie najwyższy poziom tych cech wykazują marki odzieży i innych produktów związanych z modą oraz marki pozostałych dóbr trwałego użytku, a najniższy marki żywności i kosmetyków. Te ostatnie charakteryzuje najniższa interaktywność, krótkie czasy wizyt,

${ }^{31}$ P. Kaczmarek-Kurczak: Wykorzystanie stron..., op.cit., s. 61-74. 
niewielka liczba obejrzanych stron i relatywnie wysokie współczynniki odrzuceń. Gestorzy marek odzieży i produktów związanych z modą wykazują najniższy spośród badanych kategorii branż stopień umiędzynarodowienia stron internetowych, wynikający z małej liczby wersji językowych, ograniczonych możliwości kontaktu klientów w języku obcym, najniższy odsetek odwiedzających z zagranicy i - mimo częstego oferowania zakupów przez Internet - udostępnienia tylko polskojęzycznej wersji sklepu internetowego. Najwyższym stopniem umiędzynarodowienia mierzonym liczbą zagranicznych rynków sprzedaży charakteryzują się gestorzy marek pozostałych dóbr trwałego użytku, na co spójnie wskazują dane ekonomiczne i internetowe. Wnioski z badania powinny skłonić gestorów marek eksportowych do udoskonalenia stron WWW tych marek w kierunku zwiększenia interaktywności i dostosowania do zagranicznych użytkowników.

\section{Bibliografia}

Alrawi K.: The internet and international marketing. Competitiveness Review, An International Business Journal 17(4)/2007.

Chaffey D., Mayer, R., Johnston K., Ellis-Chadwick F.: Internet Marketing, Pearson Education,

Edinburgh Gate 2000.

Chulikavit K.: E-commerce and the international distribution of SMEs. IADIS International

Conference e-Commerce 2010.

Chulikavit K., Rose J.: E-commerce and the internationalization of SMEs. Globalization and entrepreneurship: H. Etemad, R.W. Wright (red.) Policy and strategy perspectives, Northampton, MA: Edward Elgar Publishing 2003.

Davis P.S., Harveston P.D.: Internationalization and organizational growth: The impact of Internet usage and technology involvement among entrepreneur-led family businesses, Family Business Review 13 (2) /2000.

Đikanović P.: Implementing information technologies in modern business for better market positioning of companies, Megatrend revija 8 (1)/2011.

Eriksson L.T., Hultman J., Naldi L.: Small business e-commerce development in Sweden - an empirical survey. Journal of Small Business and Enterprise Development, 15(3)/2008.

Ghobakhloo M., Arias-Aranda D., Benitez-Amado J.: Adoption of e-commerce applications in SMEs, Industrial Management \& Data Systems, 111(8)/2011.

Gibb F., Matthaiakis I.: A framework for assessing web site localization, The Electronic Library, 25 (6)/2007.

Ha L., Lincoln J.: Interactivity Reexamined: A Baseline Analysis of Early Business Web Sites. Journal of Broadcasting \& Electronic Media, 42 (4)/1998.

Jaw Y.-L., Chen Ch.-L.: The influence of the internet in the internationalization of SME's in Taiwan, Human Systems Management, 25 (3)/2006.

Kaczmarek-Kurczak P.: Wykorzystanie stron internetowych przez polskich eksporterów z wybranych branż wysokich, średnich i niskich technologii, MBA, 5/2010.

Kim H., Choi Y.J., Lee Y.: Web atmospheric qualities in luxury fashion brand web sites, Journal of Fashion Marketing and Management, 19 (4)/2015.

Krulis-Randa J.S.: Megatrends und Logistik-Management, [w]: Krulis-Randa J.S., Hägeli S.W. (red.), Megatrends als Herausforderung für das Logistik-Management, Bern/Stuttgart 1992.

Mazur J., Zaborek P.: Validating DART Model, International Journal of Management and Economics 44 (1)/2014.

Mills A.J., Pitt L., Sattari S.: Reading between the vines: analyzing the readability of consumer brand wine web sites, International Journal of Wine Business Research, 24 (3)/2012.

Moini H., Tesar G.: The internet and internationalization of smaller manufacturing enterprises, Journal of Global Marketing, 18 (3-4)/2005.

Nguyen T.D.: Factors affecting the utilization of the internet by internationalizing firms in transition markets: Evidence from Vietnam, Marketing Intelligence and Planning, 25 (4)/2007.

Okazaki S.: Searching the web for global brands: how American brands standardise their web sites in Europe, European Journal of Marketing, 39(1/2)/2005.

Petersen B., Welch L.S., Liesch P.W.: The Internet and Foreign Market Expansion by Firms, MIR: Management International Review, 42 (2)/2002. 
Prahalad C. K., Ramaswamy V.: Co-creating unique value with customers, Strategy and Leadership, 32 (3) $/ 2004$.

Przybyłowski K., Hartley S., Kerin R., Rudelius W.: Marketing, Oficyna Ekonomiczna, Kraków 1998.

Reding V.: Digital Europe: the Internet mega-trends that will shape tomorrow's Europe, Speech at the European Internet Foundation Special Event A view of the Digital World in 2025, 2008.

Rzeczpospolita: Ranking Rzeczpospolitej Polskich Marek 2015, 1 grudnia 2015.

Saban K.A., Rau S.E.: The Functionality of Websites as Export Marketing Channels for Small and Medium Enterprises, Electronic Markets, 15 (2)/2005.

Saeed, S.: Exporting and the Internet: a conceptual perspective, International Marketing Review, 15 (5)/1998.

Shneor R., Flaten B-T.: The Internet-Enabled Internationalization Process: A Focus on Stages and Sequences, Journal of e-Business, Vol VIII, Nr 1-2/2008.

Simeon R.: Evaluating domestic and international Web-site strategies. Internet Research, 9(4)/1999.

Sinkovics N., Sinkovics R.R., "Bryan" Jean R. J.: The internet as an alternative path to internationalization? International Marketing Review, 30 (2)/2013.

Sørensen O. J., Buatsi S.: Internet and exporting: the case of Ghana. Journal of Business \& Industrial Marketing, 17(6)/2002.

Stephens D.O.: Megatrends in international records management. Information Management, 3(4)/2001.

Tseng K-M.K., Johnsen R.E.: Internationalisation and the internet in UK manufacturing SMEs. Journal of Small Business and Enterprise Development, 18(3)/2011.

Ulrich S.: Internetbasierte Internationalisierung, Entscheidungsfindung, Umsetzung und Erfolgsmessung, Gabler Verlag, Wiesbaden 2011.

Vargo S.L., Lusch R.F.: Evolving to a New Dominant Logic in Marketing, Journal of Marketing Vol. 68/2004. Wawrzyński M.: Urbanizacja, komunikacja lotnicza, cyfryzacja człowieka - kluczowe megatrendy zmian XXI. [w]: Przyszłość. Świat-Europa-Polska. 2/2012.

Yu J., de Koning A., Oviatt B.M.: Institutional and Economic Influences on Internet Adoption and Accelerated Firm Internationalization. [w]: Shepherd D.A., Katz J.A. International Entrepreneurship, Advances in Entrepreneurship, Firm Emergence and Growth, 8, Emerald Group Publishing Limited 2005.

\section{Summary}

The aim of this paper is to answer the research question: Do the characteristics of Polish brands' websites addressed to the domestic and foreign consumers demonstrate significant differences in terms of the industry specificity?

For this purpose, quantitative research was carried out by observing and recording the characteristics of the exporting brands' websites, supplemented with secondary data on Internet traffic and the financial outcomes of the brands' owners. The research community constisted of 402 strongest Polish consumer goods' brands sold in foreign markets.

It has been found that the brands of clothing and other fashion-related products and brands of consumer durable goods demonstrate relatively high level of surveyed Web site characteristics and brands of food and cosmetics - the lowest.

Key words: Internet domain names' characteristics, web sites, internationalization, Polish brands

Informacje o autorach:

profesor nadzwyczajny dr hab. Marzanna K. Witek-Hajduk

dr Piotr Zaborek

prof. dr hab. Jolanta Mazur

prof. dr hab. Andrzej Sznajder

dr Bartosz Targański

Szkoła Główna Handlowa,

Kolegium Gospodarki Światowej

Instytut Międzynarodowego Zarządzania i Marketingu

budynek M, parter, ul. Madalińskiego 6/8, sekretariat pok. nr 10, 02-513 Warszawa

email: mwitek@sgh.waw.pl 